\section{Research Article}

(C) 2021 Musyaffi et al. This is an open access article licensed under the Creative Commons Attribution-NonCommercial 4.o International License

(https://creativecommons.org/licenses/by-nc/4.o/)

\title{
Digital Payment During Pandemic: An Extension of The Unified Model of QR Code
}

\author{
Ayatulloh Michael Musyaffi ${ }^{1}$ \\ Razana Juhaida Johari \\ Ida Rosnidah ${ }^{3}$ \\ Dewi Agustin Pratama Sari ${ }^{1}$ \\ Muhammad Ihlashul Amal ${ }^{4}$ \\ Innaka Tasyrifania ${ }^{1}$ \\ Sekar Ayu Pertiwia ${ }^{1}$ \\ Febe Dwi Sutanti ${ }^{1}$ \\ ${ }^{1}$ Universitas Negeri Jakarta, Jl. R.Mangun Muka Raya No.11, RT.11/RW.14, \\ Rawamangun, Kec. Pulo Gadung, Kota Jakarta Timur, \\ Daerah Khusus Ibukota Jakarta 13220, Indonesia \\ ${ }^{2}$ Universiti Teknologi MARA, Jalan Ilmu 1/1, 40450 Shah Alam, Selangor, Malaysia \\ ${ }^{3}$ Universitas Swadaya Gunung Jati, Jl. Pemuda Raya No.32, Sunyaragi, \\ Kec. Kesambi, Kota Cirebon, Jawa Barat 45132, Indonesia \\ ${ }^{4}$ Universitas Negeri Semarang, Sekaran, Gunung Pati, \\ Semarang City, Central Java 50229, Indonesia
}

DOI: https://doi.org/10.36941/ajis-2021-0166

\section{Abstract}

$Q R$ Code Indonesian Standard (QRIS) is a digital payment system using a $Q R$ code that officially regulated in 2020. However, during the implementation of QRIS, there were still several problems, including security and data problems. The balance at the transaction time was not truncated, misuse of data, and application errors when scanning $Q R$ codes. This study aims to determine the factors that affect the acceptance of digital payments using QRIS. Especially those related to gaps in problems and research by combining the theory of acceptance and use of technology (UTAUT) and other variables that are also a problem in applying digital payments Security and Trust. The target population of this study is all digital payment users who use QRIS. Through the convenience sampling method, with a sample of 205 respondents. The questionnaire is distributed through an online questionnaire with Microsoft form. After that, the data will be evaluated using the Structural Equation Model (SEM) - Partial Least Square (PLS). The study results show that security as a reference is fundamental for users to increase their intention to use $Q R$ codes. Meanwhile, other components such as performance expectations and trust have proven to be essential components in initiating the intention to use digital payments using $Q R$ Code. However, not all variables from UTAUT have a significant impact, such as effory expectations. This is because an essential point in using digital payments using $Q R$ codes, especially during a pandemic, requires more security and productivity.

Keywords: Digital Payment, Perceived Security, QR Code Payment, Trust, UTAUT 


\section{Introduction}

The impact of the Covid pandemic has changed people's behavior. During pandemic, the number of unemployed increased due to the absence of employment opportunities, which was 2.56 million people, did not work due to the impact of covid by 1.77 million people, and there was a reduction in working hours of $\mathbf{2 4 . 0 2}$ million people (Dailysocial \& DSResearch, 2020). Society is now starting to be limited in social interactions, including the habit of carrying out transactions. Transactions using banknotes have the potential to spread the virus from one person to another. This has resulted in a new pattern of habits that are changing in both the business and social sectors. Then digital payments are a solution. One of them is through the QR Code. QR code is a form of digital payment that can make payments by scanning a QR code. In Indonesia, QR code payments have been regulated in the QR Code Indonesian Standard (QRIS). QR Code Indonesian Standard (QRIS) is one of the 3 main business models in digital payments. Since the implementation of strict standards by Bank Indonesia in 2019, a total of 12 digital payment sub-segment providers in 2020 in the second quarter were followed by e-money and payment gateways.

Data from Bank Indonesia as of February 2021 recorded that as many as 49 companies had obtained the QRIS service provision license. During the Covid 19 Pandemic, electronic cashless transactions based on digital payments experienced a significant increase through various applications such as mobile banking, QRIS, and cloud-based electronic money applications. The increase in the number of digital payment users in Indonesia is higher than bank accounts (Agusta \& Hutabarat, 2018). This shows a huge potential for the development of digital payment trends in the future. However, this data is different from the exposure of other researchers who say that around $73 \%$ on average mobile payment users in China are concerned about security risks and transactions using mobile payment (Lu et al., 2011). The rise in cases of theft and misuse of accounts has prompted the government to provide regulators to regulate digital payments. Meanwhile, in mid-2019 Bank Indonesia has regulated the use of a digital payment with the QRIS transaction type. This policy must be implemented on January 1, 2020. The purpose of this regulation is to provide adequate security standards and increase public trust in the digital payment model, especially by using QR Code. Based on the delloite report, the number of QR Code Payment users in Indonesia has reached 2.6 million micro enterprises, 685 thousand small businesses, 334 thousand medium enterprises, 190 thousand large enterprises, and 9.3 thousand social enterprises (Deloitte, 2020).

Digital payment is a payment concept that is made online. This means that there is a potential level of risk inherent in these payment methods such as data theft, hackers, and others. So, in a situation that is completely uncertain, trust is one solution to overcome the problem (Kim et al., 2008). As many as $22 \%$ of digital payment respondents and $18 \%$ of online loans have faced system failures and cyber-attacks (Asosiasi FinTech Indonesia, 2020). This raises the user's fear of the security of digital payment applications using QR codes. During 2019, the main complaints from consumers included the long registration process, system errors, and delayed transactions (Asosiasi FinTech Indonesia, 2020). Based on a survey from e-marketers, Indonesia is a country with moderate digital payment adoption, which is $19.8 \%$ While China has adopted $81.1 \%$ digital payment (eMarketer, 2019). This is due to the low access to digital-based financial literacy in Indonesia, which only reached 31.26\% (Dailysocial \& DSResearch, 2020). For consumers, the most important points in the adoption of digital payments are privacy, data security, transparency, and fair treatment (Asosiasi FinTech Indonesia, 2020). This difference in view makes a difference in the acceptance of digital payment users. Based on the UTAUT model, the factors that influence a person's acceptance are the level of their effort in using the system. An information technology has a positive contribution to users if the technology can support user performance, for example making what the user is doing faster (Musyaffi \& Muna, 2020).

The theory that measures the level of acceptance of an information technology includes the Unified theory of acceptance and use of technology (UTAUT). In this theory, it is explained that the effort expectancy and performance expectancy factors are important factors in making someone 
accept new technology. the easier the effort a person makes in using the technology, the more likely it is that users will continue to use the technology (Eneizan et al., 2019; Khalilzadeh et al., 2017; Mohd Thas Thaker et al., 2021; Musyaffi, 2020; Rahi \& Abd. Ghani, 2018; Rosnidah et al., 2019; Sivathanu, 2019; Xu et al., 2019). Although other research even has insignificant results between performance expectancy, for example in research on mobile banking (Merhi et al., 2019) and mobile payment (Md. A. Hossain, 2019). And the results are not significant regarding effort expectancy in the field of maritime information systems (Wiafe et al., 2019) and mobile payment (Md. A. Hossain, 2019). Of course, this is a big question regarding the gap in the results of different technology acceptance, especially research on digital payments. So, this research is here to reveal the digital payment user acceptance during pandemic based on the UTAUT model by adding the perceived security and Trust variables.

\section{Literature Review}

\subsection{Quick Response (QR) Code Payment}

Quick Response (QR) Code is a type of digital payment that uses a smartphone camera to read a barcode with a special algorithm (Surekha et al., 2015). When compared to other digital payment instruments, the use of QR Code has a faster payment speed (Surekha et al., 2015). The digital payment process using a QR Code starts with the customer selecting products and services, then the user scans using the QR code provided by the company. after that the user is asked to verify the account by entering a password. If successful, the transaction is immediately transferred from the user to the company account.

\section{$2.2 \quad U T A U T$}

In various literatures, the UTAUT model is used to measure how acceptance a person accepts technology. UTAUT is the development of various technology adoption models such as the Technology acceptance model (TAM), which is the most influential model that explains the adoption of technology use behaviors (Davis, 1989; Hasan \& Gupta, 2020). then Theory of Reasoned Action (TRA), which explains human behavior in terms of person's belief and subjective norm (Fishbein \& Ajzen, 1975), Theory of Planned Behaviour (TPB), which is the development of TAR to determine a person's attitude and behavior (Ajzen, 1991). The existence of UTAUT provides a perception of how user acceptance is measured by various variables such as performance expectancy, effort expectancy (Venkatesh et al., 2012).

In influencing someone to continuously use digital payment using QR Code, it is not only influenced by performance but also depends on the ease of using the QR Code application (Alalwan et al., 2016). Performance expectancy in this research is defined as the level of user confidence in viewing the use of digital payment as a technology that can improve performance. while Efffort expectancy is defined as a minimal effort to operate digital payment technology using QR Code. The use of QR Code that is getting easier, allows someone to continue to use this technology. Likewise, the existing technology ethics can increase work productivity, so the users' ability to adopt technology is higher. Previous literature has shown that performance expectancy has a significant impact on behavior intention (Eneizan et al., 2019; Khalilzadeh et al., 2017; Mohd Thas Thaker et al., 2021; Musyaffi, 2020; Rosnidah et al., 2019; Sabani, 2020; Sabbir et al., 2020; Sivathanu, 2019; Wiafe et al., 2019; Xu et al., 2019). Meanwhile, effort expectancy has a strong influence on performance expectancy and behavior intention (Arfi et al., 2021; Eneizan et al., 2019; Merhi et al., 2019; Mohd Thas Thaker et al., 2021; Musyaffi, 2020; Musyaffi et al., 2021; Rahi \& Abd. Ghani, 2018; Rosnidah et al., 2019; Sabbir et al., 2020; Sivathanu, 2019; Xu et al., 2019). So based on these explanations, several hypotheses that can be proposed in this study are:

$\mathrm{H}_{1}=$ Effort Expectancy has a significant positive effect on Performance Expectancy of Digital 
Payment using QR Code

$\mathrm{H} 2$ = Effort Expectancy has a significant positive effect on Behavior Intention of Digital Payment using QR Code

$\mathrm{H}_{3}=$ Performance Expectancy has a significant positive effect on Behavior Intention of Digital Payment using QR Code

\subsection{Perceived Security}

Security is the level of security that users perceive when using technology (Merhi et al., 2019; Salisbury et al., 2001). The security context in this study is related to digital payment using QR Code where the main concern is the delivery of sensitive information. It is happening because of several cases arising because of their misuse of the data. In several studies, security has become one of the most critical barriers in adopting digital payments (Kuisma et al., 2007; Luarn \& Lin, 2005).

Juang and Jing revealed that various technologies, especially digital payment should have the security that is adequate (Jung \& Jang, 2014). According to research earlier, perceived security proved to be one of the factors that is important in improving trust (Khalilzadeh et al., 2017; Mostafa, 2020; Roca et al., 2009) and behaviour intention (Alshurideh et al., 2021; Chatterjee et al., 2020; Mostafa, 2020; Semerikova, 2020). So based on these explanations, several hypotheses that can be proposed in this study are:

$\mathrm{H}_{4}=$ Perceived Security has a significant positive effect on Trust of Digital Payment using QR Code

$\mathrm{H}_{5}=$ Perceived Security has a significant positive effect on Behavior Intention of Digital Payment using QR code.

\subsection{Trust}

Trust is an important component in a person's decision to use technology. User trust arises when there is prior experience and a proven good company reputation. However, this statement cannot be confirmed when it comes to financial technology (Merhi et al., 2019). When someone already believes that the technology used has beneficial benefits for users, then performance expectancy shows a large degree (Khalilzadeh et al., 2017). Then certain emotional perceptions from users can affect the level of user trust (Kim et al., 2008). For example, performance expectancy (Khalilzadeh et al., 2017) and behavior intention (Islam \& Khan, 2021; Merhi et al., 2019).

Digital payment is a payment concept that is made online. This means that there is a potential level of risk inherent in these payment methods such as data theft, hackers, and others. It is almost impossible to use technology, especially digital payment, without having risks (Grabner-Kräuter \& Faullant, 2008) So in a situation that is completely uncertain, trust is one solution to overcome the problem (Kim et al., 2008). Previous research has shown that trust plays an important role in a person's decision to adopt technology (Arfi et al., 2021; Md. A. Hossain, 2019; Islam \& Khan, 2021; Kalinic et al., 2019; Kaur \& Arora, 2020; Merhi et al., 2019; Roca et al., 2009; Sabbir et al., 2020). So based on this explanation, several hypotheses that can be proposed in this study are:

H6 = Trust has a significant positive effect on Performance Expectancy of Digital Payment using QR Code Code

$\mathrm{H}_{7}=$ Trust has a significant positive effect on Behavior Intention of Digital Payment using QR

\section{Research Methods}

\subsection{Data Collection}

The purpose of using this method is to conclude the proposed hypothesis with statistical results. This 
study aims to describe the research population factually and accurately. The Population in this study are consumers who use digital payment methods using QR Code such as Go pay, DANA, OVO, Link Aja, Shopee Pay etc. The reason we take the consumer population of digital payment users using QR code is because currently one QR code data is becoming a nationally current issue carried out by the Indonesian government. In addition, the existence of covid causes social restrictions so that financial transactions using QR codes are very important to do as a solution during this pandemic for both consumers and entrepreneurs. The sampling technique in this study used convenience sampling. This technique was used because the number of samples in this study was relatively large. By using the Slovin formula to obtain a minimum sample size of 100 respondents (error rate $10 \%$ ). After collecting data, the number of sample size obtained is 204 respondents. Online questionnaires were distributed to respondents via Microsoft forms. Questionnaires were distributed through social media such as WhatsApp, Instagram, Facebook, and Telegram. The form is divided into several sections. First, respondents were asked to fill in general biodata such as age, gender, education, income, occupation, digital payment frequency and digital payment usage. then second, the respondent will fill out a questionnaire about his opinion in dealing with digital payment using QR Code. there are four questionnaire items about effort expectancy and performance expectancy that were adopted from related researchers (Venkatesh et al., 2012), and which are in accordance with current conditions. In addition, respondents were also asked to fill in their perceptions about trust with 4 item questionnaires (Roca et al., 2009) and perceived security (Zhou, 2011). Each Questionnaire item has 5 answer choices using a 5-point Likert scale consisting of strongly agree to strongly disagree. The reason for choosing the 5-point Likert scale is because according to previous research (Dawes, 2008), the 5-point scale has a higher score than the 10-point Likert.

Table 1 below shows the characteristics of the respondents in this study. On average these respondents are women $(66.7 \%)$. Meanwhile, in terms of education, the majority are undergraduate $(62.3 \%)$ and high school $(27 \%)$. A total of $82.8 \%$ of respondents in the study have an income below 3 million. Meanwhile, in terms of usage, most users use digital payments during the pandemic several times a month (22.1\%) and A few times a week (20.6\%).

Table 1: Descriptive statistic of respondent characteristic

\begin{tabular}{llcc}
\hline Variable & Category & Frequency & Presentage \\
\hline Gender & Man & 68 & $33.3 \%$ \\
& Woman & 136 & $66.7 \%$ \\
Education & High School & 55 & $27.0 \%$ \\
& Undergraduate & 127 & $62.3 \%$ \\
& Graduate & 21 & $10.3 \%$ \\
Revenue (idr/month) & Postgraduate & 1 & $0.5 \%$ \\
& below 3 million & 169 & $82.8 \%$ \\
Frequency to use & $3-5$ million & 16 & $7.8 \%$ \\
& 6 - 10 million & 11 & $5.4 \%$ \\
& 11 - 2o million & 7 & $3.4 \%$ \\
& A few times a week & 42 & $\mathbf{2 0 . 6 \%}$ \\
& once a week & 24 & $11.8 \%$ \\
& Twice a week & 8 & $3.9 \%$ \\
& a few time a month & 45 & $22.1 \%$ \\
\hline
\end{tabular}

\subsection{Data Analysis}

To find out how the results of the proposed hypothesis have been proven, it must first be tested with appropriate methods and analysis. This research uses Structural Equation Model (SEM) data analysis using Partial Least Square (PLS). PLS is used to predict whether the model that has been built is 
suitable in theory and practice. The stages in PLS include analyzing measurement models. Measurement model analysis is used to evaluate the validity and reliability of data. After the data has met the elements of validity and reliability, the next step is to perform a structural model analysis. This analysis is used to determine whether the model that has been built is appropriate or has several shortcomings. Finally, perform statistical analysis and evaluation of hypotheses.

\section{Result}

\subsection{Measurement Model}

The first step in interpreting the results of data processing using PLS is to analyze a measurement model. This section will explain the validity and reliability of constructs through evaluating the results of outer loading. After that, through the evaluation of Average Variance Extracted, Composite Reliability, and Discriminant Validity. Figure 1 below shows the value of outer loading, which is as follows.

Figure 1: Outer loading

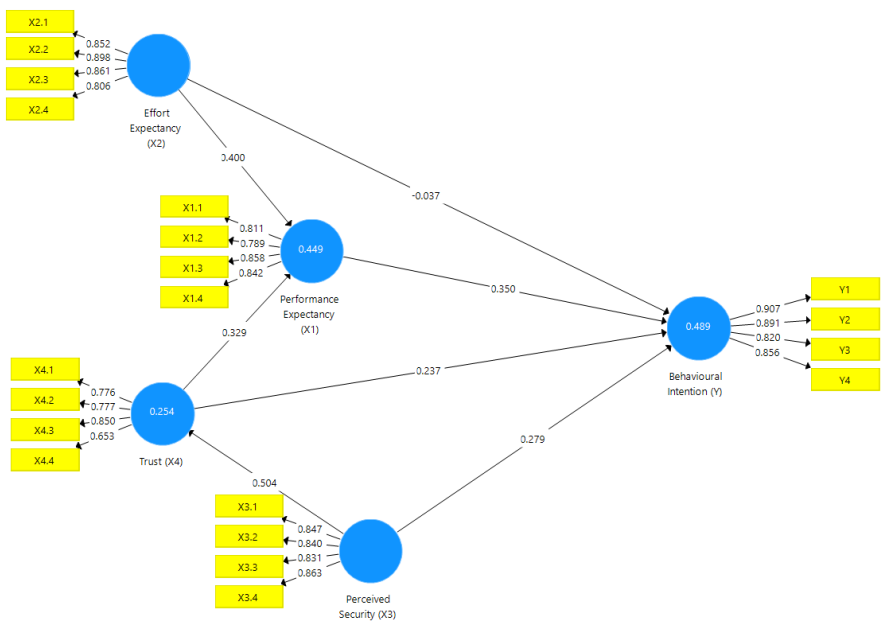

Based on the table above, the outer loading value for all constructs exceeds the value o.6. Thus, further evaluation can be carried out. After completing outer loading, the next step is to test using AVE with the recommended value above 0.5. Meanwhile, the CA and SR values must be above 0.7. Table 2 below shows the values of AVE, CA, and CR

Table 2: Validity and Reliability

\begin{tabular}{lccc}
\hline & CA & CR & AVE \\
\hline Performance Expectancy & 0.844 & 0.895 & 0.682 \\
Effort Expectancy & 0.877 & 0.916 & 0.731 \\
Perceived Security & 0.867 & 0.909 & 0.714 \\
Trust & 0.764 & 0.850 & 0.588 \\
Behavior Intention & 0.892 & 0.925 & 0.755 \\
\hline
\end{tabular}

Based on table 2 above, the CA value on all variables has a value of more than 0.7 where perceived security has the largest CA value. This is greater than the recommended value. So, it can be concluded that all these variables are valid. Next is to evaluate the CR value. Based on table 2 above, the $C R$ value for all variables has a value of more than 0.7 where behavior intention has a CR value of. 
So, it can be concluded that all these variables are reliable. Lastly is to evaluate the AVE value. based on table 2 above, the AVE value for all variables exceeds 0.5 as recommended. Thus, all these variables are valid. Apart from evaluating discriminant validity, heterotrait-monotrauit was used to test the validity of the data. the recommended value must be below o.9.

Table 3: The value of HTMT

\begin{tabular}{|c|c|c|c|c|c|}
\hline & $\mathrm{PE}$ & EE & PS & TS & BI \\
\hline Performance Expectancy & & 0.722 & 0.607 & & 0.705 \\
\hline Effort Expectancy & & & & & 0.519 \\
\hline Perceived Security & & 0.480 & & & 0.637 \\
\hline $\begin{array}{l}\text { Trust } \\
\text { Behavior Intention }\end{array}$ & 0.744 & 0.838 & 0.608 & & 0.681 \\
\hline
\end{tabular}

Based on table 3 above, the HTMT value for all variables is below 0.9 as recommended. Thus, all variables in this study are valid.

\subsection{Structural Model}

After evaluating the measurement model, the next step is to analyze the structural model to determine the relationship between constructs. Before recognizing measurement models, the first step is to look at multicollinearity using Collinearity Statistics (VIF). Table 4 below shows the value of VIF.

Table 4: Colinearity Statistics (VIF)

\begin{tabular}{lcc}
\hline Variable & Construct & VIF \\
\hline Performance Expectancy & PE1 & 1.776 \\
& PE2 & 2.738 \\
& PE3 & 1.916 \\
Effort Expectancy & PE4 & 2.356 \\
& EE1 & 3.027 \\
& EE2 & 2.193 \\
Perceived Security & EE3 & 2.005 \\
& EE4 & 2.196 \\
Trust & PS1 & 1.886 \\
& PS2 & 2.066 \\
Behavior Intention & PS3 & 2.537 \\
& PS4 & 1.653 \\
TS1 & 1.500 \\
& TS2 & 1.848 \\
& TS3 & 1.268 \\
& TS4 & 3.172 \\
\hline
\end{tabular}

Research must have freedom of problem regarding collinearity. So, it becomes crucial to evaluate whether the model built is free from collinearity. According to water, a construct is declared free of collinearity if the value is more than 5 . Based on table 4 above, the constructed value in this study is below 5, with the most considerable value on Bl1 of 3.172. This proves that all constructs in this study do not have problems regarding collinearity. 


\subsection{Hypothesis Testing}

After evaluating the measurement model and structural model, the next step is to test the hypothesis. Hypothesis testing is carried out to find out how the statistical results of the proposed hypothesis. Table 5 below shows the results of hypothesis testing through SmartPLS, which are as follows:

Table 5: Hypothesis Testing

\begin{tabular}{lccc}
\hline Variable & Original Sample & Construct & VIF \\
\hline Effort Expectancy $\left(\mathrm{X}_{2}\right)->$ Behavioral Intention $(\mathrm{Y})$ & -0.037 & 0.320 & Not Support \\
Effort Expectancy $\left(\mathrm{X}_{2}\right)->$ Performance Expectancy $\left(\mathrm{X}_{1}\right)$ & 0.400 & 0.000 & Support \\
Perceived Security $\left(\mathrm{X}_{3}\right)$-> Behavioral Intention $(\mathrm{Y})$ & 0.279 & 0.000 & Support \\
Perceived Security $\left(\mathrm{X}_{3}\right)->$ Trust $\left(\mathrm{X}_{4}\right)$ & 0.504 & 0.000 & Support \\
Performance Expectancy $\left(\mathrm{X}_{1}\right)->$ Behavioral Intention $(\mathrm{Y})$ & 0.350 & 0.000 & Support \\
Trust $\left(\mathrm{X}_{4}\right)$-> Behavioral Intention $(\mathrm{Y})$ & 0.237 & 0.007 & Support \\
Trust $\left(\mathrm{X}_{4}\right)$-> Performance Expectancy $\left(\mathrm{X}_{1}\right)$ & 0.329 & 0.000 & Support \\
\hline
\end{tabular}

Table 5 above shows that of the seven hypotheses that have been proposed, there are six supporting hypotheses following the results statistically. Perceived Security ( $\mathrm{p}$-value $=0.000 \leq 0.1$ ), Performance Expectancy $(\mathrm{p}$-value $=0.000 \leq 0.1)$ and Trust $(\mathrm{p}$-value $=0.007 \leq 0.1)$ have a significant positive impact on behavior intention of QR code payment. Meanwhile, effort expectancy ( $\mathrm{p}$-value $=0.000 \leq 0.1$ ) and Trust ( $\mathrm{p}$-value $=0.000 \leq 0.1$ ) have a significant positive impact on the performance expectancy of QR code payment. However, there is 1 hypothesis has no significant effect, namely effort expectancy (pvalue $=0.320 \leq 0.1)$ on behavior Intention of QR code payment.

\section{Discussion}

Based on statistical calculations with the applied theory, perceived security is the most crucial component by contributing 50.4\% of the significant impact on trust on the use of QR Code. This illustrates that when the QR Code payment technology has sufficient security assurance, the user's performance expectancy will be even greater. The third hypothesis shows a strong influence between performance expectancy and behavior intention to use QR code payment. This shows that users need more benefits than ease of use. It is proven in this research that effort expectancy does not have a significant positive effect on the intention to use QR code payment. This occurs during a pandemic; the real user needs are not about the system's ease of use but tend to the benefits. The affected economy also contributed quite a lot where the benefit of the QR code payment took precedence. This research result is supported by other research such as Hossain and Wiafe et al. (Md. A. Hossain, 2019; Wiafe et al., 2019), where there is no positive significance between effort expectancy and behavior intention.(Eneizan et al., 2019; Khalilzadeh et al., 2017; Mohd Thas Thaker et al., 2021; Musyaffi, 2020; Rahi \& Abd. Ghani, 2018; Rosnidah et al., 2019; Sivathanu, 2019; Xu et al., 2019)

Meanwhile, during the COVID19 pandemic, security was the primary concern for users (Undale et al., 2020). In the context of security in this research, it is related to digital payment using QR Code, where the main concern is the delivery of sensitive information. This happened because several cases arose because of the misuse of data. Research conducted by Semerikova proves that perceived security is an obstacle for users to adopt the technology due to a lack of knowledge about how the technology works (Semerikova, 2020). The existence of QRIS regulations by Bank Indonesia as the banking regulator in Indonesia has increased public trust in the QR code payment method. Users are not too worried about security threats, especially on user privacy. Because this has been handled in full of government assistance. So, the intention to use digital payment using QR Code is increasing even in the era of the COVID 19 pandemic like now. Of course, the results of this research are also supported by the results of previous research where trust plays an essential role in a person's decision 
to adopt technology (Arfi et al., 2021; Md. A. Hossain, 2019; Islam \& Khan, 2021; Kalinic et al., 2019; Kaur \& Arora, 2020; Merhi et al., 2019; Roca et al., 2009; Sabbir et al., 2020).

\section{Conclusion}

This research is developing a UTAUT model that adapts to the conditions of receiving digital payments using QR Code payments, especially in a pandemic era. This research indicates that security is the most significant factor in increasing user confidence in the use of digital payment using QR codes. Based on the facts in the field, cyber-attacks tend to increase from year to year, so this is a clear warning for digital payment service providers to improve security, especially those related to user privacy data. In addition, QR code service providers must be able to provide convenience and speed to increase user intention. A QR code has proven to be a solution in the era of the COVID-19 pandemic where users do not need to make transactions physically. It is proven that the security of the QR Code system can motivate users to continue using the digital QR code payment. This is an essential lesson that to gain user trust, the significant point that must be improved is the security and performance of the QR Code system, which can increase the intention to use digital payment using QR Code. In addition, this research proves that users are susceptible to making transactions online. Because there is an intrinsic factor inherent in technology, namely security. So, trust is crucial in ensuring that the security in technology, especially digital payment using QR Code, can be controlled and accounted for by the QR Code service provider. One of the critical programs that must be considered is the use of discounts for users. Discounts prove to be a fundamental reason for users to increase motivation further to use QR codes.

\section{Acknowledgment}

The author would like to thank to Universitas Negeri Jakarta, especially for Faculty of Economics, Universitas Negeri Jakarta, for facilitating and funding this research so that the manuscript preparation process can be carried out well. The author also expresses his gratitude to the respondents who have been willing to become volunteers as respondents.

\section{References}

Agusta, J., \& Hutabarat, K. (2018). Mobile Payment In Indonesia: Race to Big Data Domination. https://mdi.vc/whitepaper/detail/3/Mobile\%2oPayments\%2oIn\%2oIndonesia\%3A\%2oRace\%2oto\%2oBig\%2 oData\%2oDomination

Ajzen, I. (1991). The theory of planned behavior. Organizational Behavior and Human Decision Processes, 5o(2), 179-211.

Alalwan, A. A., Dwivedi, Y. K., Rana, N. P. P., \& Williams, M. D. (2016). Consumer adoption of mobile banking in Jordan: Examining the role of usefulness, ease of use, perceived risk and self-efficacy. Journal of Enterprise Information Management, 29(1), 118-139. https://doi.org/10.1108/JEIM-04-2015-0035

Alshurideh, M. T., al Kurdi, B., Masa'deh, R., \& Salloum, S. A. (2021). The moderation effect of gender on accepting electronic payment technology: a study on United Arab Emirates consumers. Review of International Business and Strategy, ahead-of-print(ahead-of-print). https://doi.org/10.1108/ribs-08-2020-0102

Arfi, W. ben, Nasr, I. ben, Kondrateva, G., \& Hikkerova, L. (2021). The role of trust in intention to use the IoT in eHealth: Application of the modified UTAUT in a consumer context. Technological Forecasting and Social Change, 167, 120688. https://doi.org/10.1016/j.techfore.2021.120688

Asosiasi FinTech Indonesia. (2020). Annual member Survey.

Chatterjee, S., Ghosh, S. K., Chaudhuri, R., \& Chaudhuri, S. (2020). Adoption of AI-integrated CRM system by Indian industry: from security and privacy perspective. Information and Computer Security. https://doi.org/10.1108/ICS-02-2019-0029

Davis, F. D. (1989). Perceived usefulness, perceived ease of use, and user acceptance of information technology. MIS Quarterly: Management Information Systems, 13(3), 319-339. https://doi.org/10.2307/249008 
Dawes, Dr. J. (2008). Do Data Characteristics Change According to the Number of Scale Points Used? An Experiment Using 5-Point, 7-Point and 10-Point Scales: Https://Doi.Org/10.1177/147078530805000106, 50(1), 61-77. https://doi.org/10.1177/147078530805000106

Deloitte. (2020). Deloitte Indonesia Business and Industry Updates: The accelerating digital payments landscape in Indonesia.

Eneizan, B., Mohammed, A. G., Alnoor, A., Alabboodi, A. S., \& Enaizan, O. (2019). Customer acceptance of mobile marketing in Jordan: An extended UTAUT2 model with trust and risk factors. International Journal of Engineering Business Management, 11. https://doi.org/10.1177/1847979019889484

Fishbein, M., \& Ajzen, I. (1975). E Ajzen, I.

Grabner-Kräuter, S., \& Faullant, R. (2008). Consumer acceptance of internet banking: The influence of internet trust. International Journal of Bank Marketing, 26(7), 483-504. https://doi.org/10.1108/02652320810913855

Hasan, A., \& Gupta, S. K. (2020). Exploring Tourists' Behavioural Intentions Towards Use of Select Mobile Wallets for Digital Payments. Paradigm, 24(2), 177-194. https://doi.org/10.1177/o971890720959519

Hossain, Md. A. (2019). Security perception in the adoption of mobile payment and the moderating effect of gender. PSU Research Review, 3(3), 179-190. https://doi.org/10.1108/prr-03-2019-0oo6

Islam, M. T., \& Khan, M. T. A. (2021). Factors influencing the adoption of crowdfunding in Bangladesh: A study of start-up entrepreneurs. Information Development, 37(1), 72-89. https://doi.org/10.1177/0266666919895554

Jung, I. Y., \& Jang, G.-J. (2014). A secure and reliable e-Wallet using a smart SSD. Life Science Journal, 11(7).

Kalinic, Z., Marinkovic, V., Molinillo, S., \& Liébana-Cabanillas, F. (2019). A multi-analytical approach to peer-topeer mobile payment acceptance prediction. Journal of Retailing and Consumer Services, 49, $143-153$. https://doi.org/10.1016/j.jretconser.2019.03.016

Kaur, S., \& Arora, S. (2020). Role of perceived risk in online banking and its impact on behavioral intention: trust as a moderator. Journal of Asia Business Studies. https://doi.org/10.1108/JABS-08-2019-0252

Khalilzadeh, J., Ozturk, A. B., \& Bilgihan, A. (2017). Security-related factors in extended UTAUT model for NFC based mobile payment in the restaurant industry. Computers in Human Behavior, 70, $460-474$. https://doi.org/10.1016/j.chb.2017.01.001

Kim, D. J., Ferrin, D. L., \& Rao, H. R. (2008). A trust-based consumer decision-making model in electronic commerce: The role of trust, perceived risk, and their antecedents. Decision Support Systems, 44(2), 544564. https://doi.org/10.1016/j.dss.2007.07.001

Kuisma, T., Laukkanen, T., \& Hiltunen, M. (2007). Mapping the reasons for resistance to Internet banking: A means-end approach. International Journal of Information Management, 27(2), $75-85$. https://doi.org/10.1016/j.ijinfomgt.2006.08.006

Lu, Y., Yang, S., Chau, P. Y. K., \& Cao, Y. (2011). Dynamics between the trust transfer process and intention to use mobile payment services: A cross-environment perspective. Information and Management, 48(8), $393-403$. https://doi.org/10.1016/j.im.2011.09.006

Luarn, P., \& Lin, H. H. (2005). Toward an understanding of the behavioral intention to use mobile banking. Computers in Human Behavior, 21(6), 873-891. https://doi.org/10.1016/j.chb.2004.03.003

Merhi, M., Hone, K., \& Tarhini, A. (2019). A cross-cultural study of the intention to use mobile banking between Lebanese and British consumers: Extending UTAUT2 with security, privacy and trust. Technology in Society, 59, 101151. https://doi.org/10.1016/j.techsoc.2019.101151

Mohd Thas Thaker, H., Mohd Thas Thaker, M. A., Khaliq, A., Allah Pitchay, A., \& Iqbal Hussain, H. (2021). Behavioural intention and adoption of internet banking among clients' of Islamic banks in Malaysia: an analysis using UTAUT2. Journal of Islamic Marketing. https://doi.org/10.1108/JIMA-11-2019-0228

Mostafa, R. B. (2020). Mobile banking service quality: a new avenue for customer value co-creation. International Journal of Bank Marketing, 38(5), 1107-1132. https://doi.org/10.1108/IJBM-11-2019-0421

Musyaffi, A. M. (2020). Perspektif Kritis Kesuksesan Implementasi Cloud Accounting Bagi Calon Akuntan: Kajian Model UTAUT \& IS Succes Model. Substansi: Sumber Artikel Akuntansi Auditing Dan Keuangan Vokasi, 4(1), 17-38. https://doi.org/10.35837/SUBS.V4I1.810

Musyaffi, A. M., \& Muna, A. (2020). Task Technology-Fit of a Village Financial System (Siskeudes) to Increase Officers' Performance. KnE Social Sciences, 720-730.

Musyaffi, A. M., Sari, D. A. P., \& Respati, D. K. (2021). Understanding of Digital Payment Usage During COVID-19 Pandemic: A Study of UTAUT Extension Model in Indonesia. The Journal of Asian Finance, Economics and Business, 8(6), 475-482.

Rahi, S., \& Abd. Ghani, M. (2018). The role of UTAUT, DOI, perceived technology security and game elements in internet banking adoption. World Journal of Science, Technology and Sustainable Development, 15(4), 338356. https://doi.org/10.1108/wjstsd-05-2018-0040 
Roca, J. C., García, J. J., \& de la Vega, J. J. (2009). The importance of perceived trust, security and privacy in online trading systems. Information Management and Computer Security, 17(2), 96-113. https://doi.org/10.1108/09685220910963983

Rosnidah, I., Muna, A., Musyaffi, A. M., \& Siregar, N. F. (2019). Critical Factor of Mobile Payment Acceptance in Millenial Generation: Study on the UTAUT model. International Symposium on Social Sciences, Education, and Humanities (ISSEH 2018), 123-127.

Sabani, A. (2020). Investigating the influence of transparency on the adoption of e-Government in Indonesia. Journal of Science and Technology Policy Management. https://doi.org/10.1108/JSTPM-03-2020-0046

Sabbir, M. M., Islam, M., \& Das, S. (2020). Understanding the determinants of online pharmacy adoption: a twostaged SEM-neural network analysis approach. Journal of Science and Technology Policy Management. https://doi.org/10.1108/JSTPM-07-2020-0108

Salisbury, W. D., Pearson, R. A., Pearson, A. W., \& Miller, D. W. (2001). Perceived security and World Wide Web purchase intention. Industrial Management \& Data Systems, 101(4), 165-177. https://doi.org/10.1108/02635570110390071

Semerikova, E. (2020). What hinders the usage of smartphone payments in Russia? Perception of technological and security barriers. Technological Forecasting and Social Change, 161, 120312. https://doi.org/10.1016/j.techfore.2020.120312

Sivathanu, B. (2019). Adoption of digital payment systems in the era of demonetization in India: An empirical study. Journal of Science and Technology Policy Management, 1o(1), 143-171. https://doi.org/10.1108/JSTPM07-2017-0033

Surekha, A., Anand, P. R., \& Indu, I. (2015). E-payment transactions using encrypted QR codes. International Journal of Applied Engineering Research, 10(77), 461-undefined.

Undale, S., Kulkarni, A., \& Patil, H. (2020). Perceived eWallet security: impact of COVID-19 pandemic. Vilakshan XIMB Journal of Management, ahead-of-print(ahead-of-print). https://doi.org/10.1108/xjm-07-2020-0022

Venkatesh, V., Thong, J. Y. L., \& Xu, X. (2012). Consumer acceptance and use of information technology: Extending the unified theory of acceptance and use of technology. MIS Quarterly: Management Information Systems, 36(1), 157-178. https://doi.org/10.2307/41410412

Wiafe, I., Koranteng, F. N., Tettey, T., Kastriku, F. A., \& Abdulai, J. D. (2019). Factors that affect acceptance and use of information systems within the Maritime industry in developing countries: The case of Ghana. Journal of Systems and Information Technology, 22(4), 21-45. https://doi.org/10.1108/JSIT-06-2018-0091

$\mathrm{Xu}, \mathrm{Z}$., Li, Y., \& Hao, L. (2019). An empirical examination of UTAUT model and social network analysis. Library Hi Tech. https://doi.org/10.1108/LHT-11-2018-0175

Zhou, T. (2011). The effect of initial trust on user adoption of mobile payment. Information Development, 27(4). https://doi.org/10.1177/0266666911424075 